\title{
SISTEM PIDANA DAN PEMIDANAAN DI DALAM PEMBAHARUAN HUKUM PIDANA INDONESIA*
}

\author{
FAILIN \\ Sekolah Tinggi Ilmu Hukum Putri Maharaja Payakumbuh \\ Canduang Koto Laweh Kecamatan Canduang Kabupaten Agam Sumatera Barat \\ e-mail: failin.alin87@gmail.com
}

\begin{abstract}
Renewal of criminal law in the context of improving the punishment system is still continuing. Of the many things to be updated, one important thing in the penal system is also crucial provided in the reform of Indonesian criminal law is the structural punishment system. This is something that should be included in the concept of reform of criminal law. Barda Nawawi termed as an integral policy in the handling crime to mention the importance of structural punishment system, which also means integral policy in the punishment system. The problems that arise are how the criminal system and punishment in the current Penal Code and the Criminal System and Penalties in the New Criminal Code Concept as Part of the Renewal of Indonesian Penal Law. While the research method The type of research conducted is legal juridical Normative research that is about what the concept of punishment system in the renewal of criminal law in Indonesia that is by collecting data normatively and what is in the Act related to criminal law. In this paper we discussed it can be simply described, so far in the criminal system in Indonesia the focus of criminal offense and criminal responsibility is on the direct individuals involved in the criminal process. Where is often the involvement of other parties besides the individual concerned who can also be held accountable as the impact of the occurrence of a crime. A concrete example, if a child commits a criminal offense, his / her "criminal" is not only granted to the child, but to his / her parents even if the criminal sanction is for example a fine of fines. This is because using the logic that the child is still the responsibility of parents, so that parents are also responsible for the actions of his son.
\end{abstract}

Keywords: criminal system, punishment, renewal of criminal law

\begin{abstract}
Abstrak
Pembaharuan hukum pidana dalam rangka penyempurnaan sistem pemidanaan masih terus dilakukan. Dari sekian banyak hal yang akan diperbarui, satu hal penting dalam sistem pemidanaan yang juga krusial disediakan dalam pembaruan hukum pidana Indonesia adalah sistem pemidanaan struktural. Ini merupakan hal yang sebetulnya patut dimasukkan dalam konsep pembaruan hukum pidana. Barda Nawawi mengistilahkan sebagai kebijakan integral dalam penanggulangan kejahatan untuk menyebut pentingnya sistem pemidanaan struktural, yang mengandung arti pula kebijakan integral dalam sistem pemidanaan. Permasalahan yang timbul adalah bagaimana sistem pidana dan pemidanaan dalam KUHP Sekarang serta melihat Sistem Pidana Dan Pemidanaan Dalam Konsep KUHP Baru Sebagai Bagian Dari Pembaharuan Hukum Pidana Indonesia. Sedangkan metode penelitian Jenis penelitian yang dilakukan adalah penelitian hukum Yuridis Normatif yang bersifat tentang apa yang menjadi konsep sistem pemidanaan dalam pembaharuan hukum pidana di Indonesia yakni dengan mengumpulkan data secara normatif dan apa yang ada dalam Undang-undang terkait dengan hukum pidana. Dalam penulisan ini yang dibahas adalah Secara sederhana bisa digambarkan, selama ini dalam sistem pemidanaan di Indonesia fokus tindak pidana dan pertanggungjawaban pidana ada pada individu-individu langsung yang terlibat dalam proses tindak pidana. Padahal sering ada keterlibatan pihak lain selain individu bersangkutan yang juga dapat dimintai pertanggungjawaban sebagai dampak dari terjadinya suatu tindak pidana. Contoh konkret, bila seorang anak melakukan tindak pidana, "pidana"-nya tidak hanya diberikan pada anak tersebut, tetapi pada orang tuanya meskipun pidana yang dijatuhkan misalnya berupa pidana denda. Ini karena menggunakan logika bahwa anak masih merupakan tanggung jawab
\end{abstract}

\footnotetext{
* Naskah diterima: 31 Agustus 2017, direvisi: 07 Sebtember 2017, disetujui untuk terbit: 10 Sebtember 2017
} 
Failin: Sistem Pidana dan Pemidanaan di dalam Pembaharuan Hukum Pidana Indonesia

orang tua, sehingga orang tua juga bertanggung jawab terhadap perbuatan yang dilakukan anaknya.

Kata kunci: Sistem Pidana, pemidanaan, pembaharuan hukum pidana

\section{PENDAHULUAN}

Hukum merupakan suatu pedoman yang mengatur pola hidup manusia yang memiliki peranan penting dalam mencapai tujuan ketentraman hidup bagi masyarakat. Oleh karena itulah, hukum mengenal adanya adagium ibi societes ibi ius. Adagium ini muncul karena hukum ada karena adanya masyarakat dan hubungan antar individu dalam bermasyarakat. Hubungan antar individu dalam bermasyarakat merupakan suatu hal yang hakiki sesuai kodrat manusia yang tidak dapat hidup sendiri karena manusia adalah makhluk polis, makhluk yang bermasyarakat (zoon politicon). ${ }^{1}$

Semua hubungan tersebut diatur oleh hukum, semuanya adalah hubungan hukum (rechtsbetrekkingen). ${ }^{2}$ Maka untuk itulah dalam mengatur hubunganhubungan hukum pada masyarakat diadakan suatu kodifikasi hukum yang mempunyai tujuan luhur yaitu menciptakan kepastian hukum dan mempertahankan nilai keadilan dari subtansi hukum tersebut. Sekalipun telah terkodifikasi, hukum tidaklah dapat statis karena hukum harus terus menyesuaikan diri dengan masyarakat, apalagi yang berkaitan dengan hukum publik karena

1 Darji Darmodiharjo \& Shidarta, 1995, Pokok-Pokok Filsafat Hukukum, Apa dan Bagaimana Filsafat Hukum Indonesia, P.T. Gramedia Pustaka Utama, Jakarta, Hlm. 73.

2 L.J. van Apeldoorn, 2000, Pengantar Ilmu hukum, P.T. Pradnya Paramita, Jakarta, Hlm. 6. bersentuhan langsung dengan hajat hidup orang banyak dan berlaku secara umum.

Masalah pidana dan pemidanaan itu sendiri merupakan obyek kajian dalam bidang hukum pidana yang disebut hukum penitensier (penitensier recht). Oleh karena persoalan hukum pidana yang dikupas atau dibahas dalam hukum penitensier adalah menyangkut masalah pidana dan pemidanaan, maka hukum penitensier itu sendiri dalam arti sempit dapat diartikan sebagai segala peraturanperaturan positif mengenai sistem pidana (strafstelsel). Sedangkan dalam arti luas, hukum penitensier dapat diartikan sebagai bagian hukum pidana yang menentukan dan memberi aturan tentang sanksi (sistem sanksi) dalam hukum pidana, yang meliputi baik strafstelsel maupun maatregelstelsel (sistem tindakan) serta kebijaksanaan. Jadi dalam usaha untuk mempertahankan dan menyelenggarakan ketertiban, serta melindunginya dari perkosaan-perkosaan (pelanggaranpelanggaran) terhadap berbagai kepentingan hukum, maka negara diberi hak dan kekuasaan untuk menjatuhkan pidana serta hak dan kekuasaan untuk. menjatuhkan tindakan dan kebijaksanaan. $^{3}$

Pembaruan hukum pidana dalam
rangka penyempurnaan sistem
pemidanaan masih terus dilakukan. Dari

\footnotetext{
${ }^{3}$ Muladi dan Barda Nawawi Arief, Teoriteori dan kebijakan pidana, Alumni, Bandung, Hlm. 1
} 
sekian banyak hal yang akan diperbarui, satu hal penting dalam sistem pemidanaan yang juga krusial disediakan dalam pembaruan hukum pidana Indonesia adalah sistem pemidanaan struktural. Ini merupakan hal yang sebetulnya patut dimasukkan dalam konsep pembaruan hukum pidana. Menurut Barda Nawawi Arief, hukum pidana seharusnya tidak hanya berfungsi fragmenter, tapi harus totalitas dan struktural. $^{4}$ Selama ini hukum pidana Indonesia yang merupakan turunan langsung dari Weetboek van Straftrecht (WvS) Belanda masih memberlakukan hukum pidana secara individual, padahal model ini sudah mulai dianggap tidak proporsional lagi.

Ternyata dalam logika dan fakta hukum, sering tindak pidana tidak hanya bisa dilakukan individual sehingga pertanggungjawaban pidananya pun tidak bisa individual. Dalam berbagai bentuk tindak pidana (baik WvS maupun konsep baru KUHP) juga diatur tentang adanya "pelaku", "yang menyuruh melakukan", dan "turut serta melakukan" tindak pidana. Logika pertanggungjawaban struktural merupakan kaitan yang boleh jadi menginspirasi atau lalai baik terhadap pengawasan maupun tanggung jawab sehingga terjadinya tindak pidana. Artinya bahwa jelas dalam tindak pidana dan pertanggungjawaban pidana dapat melibatkan pihak lain selain pelaku secara individual. Pertanggungjawaban pidana dalam hal ini tidak bisa dilihat hanya dalam pelaksanaan tindak pidana, tetapi

4 Jinmmy Asshidigie, 2000, Agenda Pembangunan Hukum Nasional Di Abad Glohalisasi, Sinar Grafika, Jakarta, Hlm. 93. juga memperhatikan hubungan-hubungan psikologis dan historis pelaku tindak pidana, yang tetap harus dalam bingkai rasionalitas.

Barda Nawawi mengistilahkan sebagai kebijakan integral dalam penanggulangan kejahatan untuk menyebut pentingnya sistem pemidanaan struktural, yang mengandung arti pula kebijakan integral dalam sistem pemidanaan. Secara sederhana bisa digambarkan, selama ini dalam sistem pemidanaan di Indonesia fokus tindak pidana dan pertanggungjawaban pidana ada pada individu-individu langsung yang terlibat dalam proses tindak pidana.

Padahal sering ada keterlibatan pihak lain selain individu bersangkutan yang juga dapat dimintai pertanggungjawaban sebagai dampak dari terjadinya suatu tindak pidana. Contoh konkret, bila seorang anak melakukan tindak pidana, "pidana"-nya tidak hanya diberikan pada anak tersebut, tetapi pada orang tuanya meskipun pidana yang dijatuhkan misalnya berupa pidana denda. Ini karena menggunakan logika bahwa anak masih merupakan tanggung jawab orang tua, sehingga orang tua juga bertanggung jawab terhadap perbuatan yang dilakukan anaknya.

Model ini tampaknya lebih memberikan efek jera baik bagi anak yang melakukan tindak pidana maupun orang tua yang selama ini lalai memberikan pengawasan pada anaknya. Contoh analogi lainnya adalah jika seorang menderita kerugian akibat tindak kejahatan yang terjadi di suatu daerah, 
Failin: Sistem Pidana dan Pemidanaan di dalam Pembaharuan Hukum Pidana Indonesia

kepala daerah setempat dapat dimintai pertanggungjawaban akibat tindak kejahatan di daerahnya merugikan orang lain. Ini bisa terjadi mengingat kepala daerah bertanggung jawab terhadap seluruh wilayah yang dipimpinnya; tidak memberikan rasa aman. Yang lebih penting dari kedua contoh tersebut adalah upaya pencapaian terhadap tujuan pemidanaan, yakni keadilan. Jadi selain kepastian hukum seperti yang tampak pada contoh pertama, juga mengarah kepada keadilan seperti pada kedua contoh. Selain sebagai bentuk pemenuhan rasa keadilan, penerapan pertanggungjawaban pidana secara struktural juga mencerminkan kesungguhan penguasa untuk dapat berada dalam "status" yang sama dengan masyarakat biasa di mata hukum. Bentuk sistem pemidanaan stuktural merupakan keniscayaan dalam pembaruan hukum pidana Indonesia. Bahkan di beberapa Undang-undang khusus di luar KUHP mengatur tentang sistem pemidanaan struktural, meskipun masih bermasalah dalam pelaksanaannya.

Pemidanaan secara sederhana dapat diartikan dengan penghukuman. Penghukuman yang dimaksud berkaitan dengan penjatuhan pidana dan alasanalasan pembenar (justification) dijatuhkannya pidana terhadap seseorang yang dengan putusan pengadilan yang telah berkekuatan hukum tetap (incracht van gewijsde) dinyatakan secara sah dan meyakinkan terbukti melakukan tindak pidana. Tentunya, hak penjatuhan pidana dan alasan pembenar penjatuhan pidana serta pelaksanaannya tersebut berada penuh di tangan negara dalam realitasnya sebagai roh.

Sesuai dengan apa yang dikatakan oleh Barda Nawawi Arief: bahwa tujuan dari kebijakan pemidanaan yaitu menetapkan suatu pidana tidak terlepas dari tujuan politik kriminal. Dalam arti keseluruhannya yaitu perlindungan masyarakat untuk mencapai kesejahteraan. Oleh karena itu untuk menjawab dan mengetahui tujuan serta fungsi pemidanaan, maka tidak terlepas dari teori-teori tentang pemidanaan yang ada.

Patut diketahui, bahwa tidaklah semua filsuf ataupun pakar hukum pidana sepakat bahwa negaralah yang mempunyai hak untuk melakukan pemidanaan (subjectief strafrech). Hal ini dapat terlihat jelas pada pendapat Hezewinkel-Suringa yang mengingkari sama sekali hak mempidana ini dengan mengutarakan keyakinan mereka bahwa si penjahat tidaklah dilawan dan bahwa musuh tidaklah boleh dibenci. ${ }^{5}$ Pendapat ini dapat digolongkan sebagai bentuk negativisme, dimana para ahli yang sependapat dengan Suringa tersebut menyatakan hak menjatuhkan pidana sepenuhnya menjadi hak mutlak dari Tuhan.

Negativisme yang dimaksud di atas, penulis anggap sebagai bentuk penegakan hukum secara utopis di masa sekarang ini, dikarenakan penegakan hukum agama

5 Wirjono Prodjodikoro, 2008, Asas-Asas Hukum Pidana di Indonesia, PT. Refika Aditama, Bandung, Hlm. 23. 
menganggap Negara adalah perpanjangan tangan Tuhan di dunia. Sementara itu, dewasa ini cenderung untuk mengkotomikan antara konsep-konsep sistem pemerintahan dan penegakan hukum dengan ajaran-ajaran agama tertentu. Bagi kalangan religius hal ini dianggap menuju arah paham sekularisme (walaupun tidak secara absolut), namun hal ini semakin hari-hari semakin banyak dipraktekkan pada banyak Negara pada sistem ketatanegaraan yang berimplikasi pada bentuk hukum pidana positif. Hal ini dapat terlihat jelas pada Negara kita dengan tidak diberlakukannya hukum agama secara mutlak dalam hukum nasional kita (faktor kemajemukan sosial) dan juga pada Negara-negara lainya.

Jadi, dapatlah kita berpedoman pada mazhab wiena yang menyatakan hukum dan negara adalah identik, karena adalah tak lain daripada satu susunan tingkah laku manusia dan satu ketertiban paksaan kemasyarakatan. ${ }^{6}$

Di dalam KUHP bila sudah diketahui bahwa pentingnya pemidanaan struktural, patut dipikirkan rumusannya yang tepat untuk memenuhi kebutuhan hukum positif. Kita dapat beranjak dari perbandingan pemidanaan struktural yang diberlakukan di negara lain, terkait dasar atau landasan filosofis pengaturan, aturan hukum positif, dan model pertanggungjawaban pidananya.

Landasan filosofis bagi KUHP untuk penerapan pemidanaan struktural adalah berpegang pada bahwa

${ }^{6}$ Soetiksno, 2008, Filsafat Hukum Bagian I, PT. Pradnya Paramita, Jakarta, Hlm. 67. pertanggungjawaban pidana terkadang melibatkan pihak lain selain pelaku, tindak pidana, atau adanya kelalaian dalam menjalankan kebijakan sehingga terjadi tindak pidana yang tidak dinginkan. Dalam konsep pembaruan KUHP di Indonesia, ide ini dicerminkan dalam "ide keseimbangan/monodualistik". Selama ini kita hanya berpegang pada adanya kesalahan dalam tindak pidana, atau sering disebut "tiada pidana tanpa kesalahan" (asas culpabilitas), meskipun dalam KUHP lama (WvS) hal ini juga belum diatur. Namun dalam perkembangan saat ini, asas itu tidak cukup. Saat ini hukum pidana lebih menuntut adanya keseimbangan karena melihat tujuan adanya hukum adalah keadilan, kemanfaatan, dan kepastian hukum. Bila selama ini kita hanya melihat hukum sebagai sesuatu untuk mencapai kepastian hukum, hal inilah yang perlu dibenahi.

Konsep KUHP baru yang idenya adalah keseimbangan, maka upaya untuk mencapai tujuan yang lain yakni keadilan dan kemanfaatan juga akan diakomodasi, yang salah satunya sebenarnya bisa dalam bentuk pengaturan pemidanaan struktural. Apalagi bila mengingat salah satu ide dasar sistem pemidanaan dalam konsep KUHP baru adalah ide mendahulukan keadilan dari kepastian hukum. Bila ternyata dalam konsep KUHP baru belum tercermin tentang pemidanaan struktural, hal ini mesti dapat dijadikan ide untuk perbaikan KUHP selanjutnya mengingat pembaruan hukum pidana tidak hanya 
Failin: Sistem Pidana dan Pemidanaan di dalam Pembaharuan Hukum Pidana Indonesia

berhenti sampai saat ini, tetapi menurut Prof. Soedarto harus terus berlanjut.

\section{METODE PENELITIAN}

Jenis penelitian yang dilakukan adalah penelitian hukum Yuridis Normatif yang bersifat tentang apa yang menjadi konsep sistem pemidanaan dalam pembaharuan hukum pidana di Indonesia yakni dengan mengumpulkan data secara normatif dan apa yang ada dalam Undang-undang terkait dengan hukum pidana.

\section{HASIL DAN PEMBAHASAN}

\section{Sistem Pidana Dan Pemidanaan Dalam KUHP Sekarang}

Andi Hamzah memberikan arti sistem pidana dan pemidanaan sebagai susunan (pidana) dan cara pemidanan. M. Sholehuddin menyatakan, bahwa masalah sanksi merupakan hal yang sentral dalam hukum pidana karena seringkali menggambarkan nilainilai sosial budaya suatu bangsa. Artinya pidana maengandung tata nilai (value) dalam suatu masyarakat mengenai apa yang baik dan yang tidak baik, apa yang bermoral dan apa yang amoral serta apa yang diperbolehkan dan apa yang dilarang. ${ }^{7}$

Sistem merupakan jalinan dari beberapa unsur yang menjadi satu fungsi. Sistem pemidanaan memegang posisi strategis dalam upaya untuk menanggulangi tindak pidana yang terjadi. Sistem pemidanaan adalah suatu

7 Ekaputra, Mohammad dan Abul Khair, 2010, Sistem Pidana Di Dalam KUHP Dan, Pengaturannya menurut Konsep KUHP Baru, USU Press, Medan, Hlm. 13. aturan perundang-undangan yang berhubungan dengan sanksi pidana dan pemidanaan. Apabila pengertian sistem pemidanaan diartikan secara luas sebagai suatu proses pemberian atau penjatuhan pidana oleh hakim, maka dapatlah dikatakan bahwa sistem pemidanaan mencakup keseluruhan ketentuan perundang-undangan yang mengatur bagaimana hukum pidana itu ditegakkan atau dioperasionalkan secara konkret sehingga seseorang dijatuhi sanksi (hukum) pidana.

Ini berarti semua aturan perundangundangan mengenai hukum pidana subtantif, hukum pidana formal dan hukum pelaksanaan pidana dapat dilihat sebagai satu kesatuan sistem pemidanaan. Dengan demikian dapatlah dikatakan bahwa pemidanaan tidak dapat terlepas dari jenis-jenis pidana yang diatur dalam hukum positif suatu negara. Pemidanaan yang dilakukan oleh suatu masyarakat yang teratur terhadap pelaku kejahatan dapat berbentuk menyingkirkan atau melumpuhkan para pelaku tindak pidana, sehingga pelaku tersebut tidak lagi menggangu di masa yang akan datang.

Prof, van Hammel mengartikan pidana (straf) menurut hukum positif sebagai suatu penderitaan yang bersifat khusus. Penderitaan tersebut menurut van Hammel dijatuhkan oleh kekuasaan yang berwenang untuk menjatuhkan pidana atas nama negara sebagai penangung jawab ketertiban hukum umum bagi seorang pelanggar, penderitaan itu dikenakan semata-mata karena orang tersebut telah melanggar suatu peraturan 
hukum yang harus ditegakkan oleh negara. $^{8}$

Sementara itu Prof Simon juga mengartikan pidana (straf) sebagai suatu penderitaan yang ditimpakan kepada seseorang, penderitaan tersebut oleh undang-undang pidana dikaitkan dengan telah terjadinya pelanggaran terhadap suatu norma, yang dengan suatu putusan hakim telah dijatuhkan bagi seseorang yang bersalah. ${ }^{9}$

Kedua ahli hukum pidana Belanda ini memiliki pandangan yang sama dalam memberikan batasan tentang pidana, yang pada hakikatnya adalah suatu penderitaan. Namun harus dipahami, bahwa penderitaan tersebut bukanlah merupakan suatu tujuan; melainkan hanyalah sematamala sebagai alat yang digunakan oleh negara untuk mengingatkan agar orang tidak melakukan kejahatan. ${ }^{10}$

Para ahli hukum pidana Indonesia ternyata juga memiliki pandangan yang sama dengan dalam memahami dan memberikan alasan terhadap konsep pidana. Menurul Prof Sudarto, secara tradisional pidana dapat didefinisikan sebagai nestapa yang dikenakan oleh negara kepada seseorang yang melakukan pelanggaran terhadap ketentuan undangundang, sengaja agar rasakan sebagai nestapa. $^{11}$ Sementara itu, Prof Roeslan Saleh mengartikan pidana sebagai reaksi

\footnotetext{
${ }^{8}$ Lihat Lamintang, Op.Cit, Hlm.34

${ }^{9}$ Ibid, Hlm. 34-35.

10 Andi Hamzah, 1986, Sistem Pidana danPemidanaan di Indonesia: dari rettribusi ke reformasi, Pradnya Paramita, Jakarta, Hlm. 34

11 Sudarto, 1996, Kapita Selekta Hukum Pidana, Alumni, Bandung, Hlm. 109-110.
}

atas delik, dan ini berujud suatu stapa yang dengan sengaja ditimpakan negara pada pembuat delik itu. ${ }^{12}$

Dalam memberikan pemahaman terhadap konsep pidana, maka setelah mengemukakan berbagai definisi, akhirnya Prof Muladi ampai kepada sebuah kesimpulan lentang unsur-unsur atau ciri-ciri yang terkandung di dalam pidana, yaitu: ${ }^{13}$
a. Pidana itu pada hakikatnya merupakan suatu pengenaan penderitaan atau nestapa atau akibat-akibat lain yang tidak menyenangkan;

b. Pidana itu diberikan dengan sengaja oleh orang atau badan yang mempunyai kekuasaan (oleh yang berwenang);

c. Pidana itu dikenakan kepada seseorang yang telah melakukan tindak pidana menurut undangundang.

Terdapat kesamaan pendapat dalam memahami pengertian pidana, di mana salah satu karakteristiknya adalah adanya pengenaan nestapa atau penderitaan dengan sengaja. Ciri ini erat kaitannya dengan sifat hukum pidana yang dengan sengaja mengenakan penderitaan dalam mempertahankan norma-norma yang diakui di dalam hukum. Pemberian nestapa atau penderitaan yang (sengaja dikenakan kepada seorang pelaku yang melanggar ketentuan-ketentuan hukum pidana adalah dimaksudkan untuk

\footnotetext{
12 Roeslan Saleh, 1987, Stesel Pidana Indonesia, Bina Aksara, Jakarta, Hlm. 5

${ }^{13}$ Muladi, Op.Cit, Hlm. 6
} 
Failin: Sistem Pidana dan Pemidanaan di dalam Pembaharuan Hukum Pidana Indonesia

menimbulkan efek penjeraan, sehingga orang tidak melakukan tindak pidana, dan pelaku tidak lagi mengulangi melakukan kejahatan.

Akan tetapi tidak semua sarjana menyetujui pendapat bahwa hakikat pidana adalah pemberian nestapa atau penderitaan. Misalnya Hulsman yang memandang pidana itu sebagai sebuah seruan untuk tertib (tot de orde roepen). ${ }^{14}$ Pidana pada hakikatnya mempunyai dua tujuan utama, yakni untuk mempengaruhi tingkah laku dan untuk menyelesaikan konflik. Penyelesaian konflik tersebut dapat terdiri dari perbaikan kerugian yang dialami atau pengembalian kepercayaan antar sesama manusia.

Setelah dipahami pengertian pidana (straf), pertanyaan selanjutnya adalah apa yang dimaksud dengan pemidanaan (mordeling), Seperti telah di kemukakan di muka, bahwa menurut Prof Sudarto perkataan pemidanaan adalah sinonim dengan istilah penghukuman. Penghukuman itu berasal dari kata dasar hukum, sehingga dapat diartikan sebagai menetapkan hukum atau memutuskan tentang hukumnya. ${ }^{15}$ Menetapkan hukum untuk suatu peristiwa itu tidaklah hanya menyangkut bidang hukum pidana saja, tetapi juga hukum perdata. Oleh karena itu, sepanjang menyangkut penghukuman dalam lapangan hukum pidana, maka istilah penghukuman harus disempitkan artinya, yaitu penghukuman dalam perkara, pidana. Untuk menyebut penghukuman dalam perkara pidana dapat

\footnotetext{
${ }^{14}$ Sudarto, Op.Cit, Hlm. 110

${ }^{15}$ Sudarto, Op.Cit, Hlm. 71
}

dipakai perkataan pemidanaan atau pemberian (penjatuhan) pidana oleh hakim.

Hakim memang harus mempertimbangkan tuntutan penuntut umum, namun ia sama sekali tidak terikat dengan tuntutan itu. Tidak jarang kita temui dalam kasus-kasus konkrit hakim menjatuhkan pidana jauh lebih rendah atau lebih tinggi dari apa yang dituntut oleh penuntut umum. Namun tidak jarang pula hakim sepakat atau konform dengan tuntutan penuntut umum. orang tidak dapat dikenakan sanksi berupa pidana di luar apa yang telah ditentukan di dalam undang-undang. Oleh karena itu dalam hal penjatuhan pidana, hakim terikat pada jenis-jenis sanksi pidana yang telah ditetapkan dalam undang-undang. Ini sudah merupakan pendirian dari Mahkamah Agung Republik Indonesia, yang secara tegas menentukan, bahwa perbuatan menambah jenis-jenis pidana yang telah ditentukan dalam Pasal 10 KUHP dengan lain-lain jenis pidana adalah terlarang. ${ }^{16}$

Hukum pidana Indonesia menentukan jenis-jenis sanksi pidana atas pidana pokok dan pidana tambahan. Hal tersebut secara tegas dirumuskan di dalam Pasal 10 KUHP yang berbunyi: ${ }^{17}$

Pidana terdiri atas:

1. Pidana Pokok:

a. Pidana mati

${ }^{16}$ Lihat Putusan Mahkamah agung Republik Indonesia tanggal 11 Maret 1970 Nomor $59 \mathrm{~K} / \mathrm{Kr} / 1973$.

${ }^{17}$ Barda Nawawi Arief, 1996, Bunga Rampai Kebijakan Hukum Pidana, Citra aditia Bakti, Bandung, Hlm. 22 
b. Pidana penjara

c. Pidana kurungan

d. Pidana denda

e. Pidana Tambahan

f. Pencabutan hak-hak tertentu

2. Perampasan barang-barang tertentu;

3. Pengumuman putusan hakim.

Kemudian, pada tahun 1916 dengan Undang-undang Nomor 20 tahun 1946, hukum pidana Indonesia mengenal suatu jenis pidana pokok yang baru, yaitu apa yang disebut pidana tutupan. Pidana penutupan ini pada hakikatnya adalah pidana penjara. Namun dalam mengadili orang yang melakukan kejahatan yang diancam dengan penjara, karena terdorong oleh maksud yang patut dihormati, maka hakim boleh menjatuhkan pidana tutupan. Inilah semua jenis pidana yang ada di dalam KUHP sekarang.

Sebagaimana telah dijelaskan sebelumnya, bahwa pidana mati masih tercantum didalam K.U.H.Pidana. Pada setiap delik yang diancam dengan pidana mati selalu tercantum alternatif pidana seumur hidup atau pidana penjara sementara dua puluh tahun, jadi hakim dapat memilih antara tiga kemungkinan tersebut melihat bentuk delik itu, maka pidana mati hanya dijatuhkan terhadap delik yang benar dianggap berat saja, dalam hal pidana mati yang dijatuhkan terpidana dapat mengajukan grasi kepada Presiden, apabila terpidana tidak memohon grasi kepada presiden berarti Presiden menyetujui eksekusi pidana mati tersebut.
Dengan demikian, bahwa sistem pemidanaan yang tercantum dalam K.U.H Pidana mengenal dua macam sistem yaitu, sistem pemidanaan alternatif dan sistem pemidanaan tunggal. Alternatif artinya bahwa hakim dalam memutuskan perkara boleh memilah dalam menjatuhkan putusannya, sedangkan sistem pemidanaan tunggal diartikan bahwa hakim dalam menjatuhkan putusannya harus sesuai dengan rumusan yang terdapat dalam Pasal tersebut.

Penjatuhan pidana mati menurut pemidanaan dalam K.U.H Pidana, selalu dialternatifkan dengan jenis pidana lainnya yaitu pidana penjara, baik pidana penjara seumur hidup maupun pidana penjara selama-lamanya 20 tahun (pidana penjara sementara waktu 20 tahun), hal ini dapat dilihat dalam perumusan Pasal 340 K.U.H Pidana tentang pembunuhan berencana. Sistem pemidanaan yang bersifat tunggal sebagaimana di anut K.U.H Pidana dapat dilihat dalam pasal 489 ayat (1) Buku ke III K.U.H Pidana tentang pelanggaran terhadap keamanan umum bagi orang dan barang. ${ }^{18}$

\section{Sistem Pidana Dan Pemidanaan Dalam Konsep KUHP Baru Sebagai Bagian Dari Pembaharuan Hukum Pidana Indonesia}

Pembaharuan secara etimologis berarti suatu hal yang "lama" dan sedang dalam prosesnya untuk diperbaharui. Telah dijelaskan di awal bahwa kebijakan

${ }^{18}$ http://repository.usu.ac.id/bitstream/handle/ 123456789/21543/Chapter\%20II.pdf;jsessionid=E 49E02C84094B1CD73517FFA85AB3C93?seque $\underline{\text { nce }=3}$, diakses pada hari jumat, tanggal 18 Agustus 2017, pada jam 12.00. 
Failin: Sistem Pidana dan Pemidanaan di dalam Pembaharuan Hukum Pidana Indonesia

hukum pidana ialah suatu usaha untuk membuat peraturan (pidana) menuju yang lebih baik, tidak hanya melakukan pengaturan tingkah laku masyarakat, namun juga menciptakan masyarakat yang sejahtera. Hal ini berarti pembaharuan hukum pidana merupakan bagian yang tak terpisahkan dari kebijakan hukum pidana.

Usaha pembaharuan hukum di Indonesia yang sudah dimulai sejak proklamasi kemerdekaan tanggal 17 Agustus 1945, melalui Undang-Undang Dasar Negara Republik Indonesia Tahun 1945 (UUD NRI 1945) tidak dapat dilepaskan dari landasan dan sekaligus tujuan nasional yang ingin dicapai seperti dirumuskan dalam Pembukaan UUD 1945, khususnya alinea ke empat.

Dari perumusan tujuan nasional yang tertuang dalam alinea ke empat UUD 1945 tersebut, dapat diketahui dua tujuan nasional yang utama yaitu: (1) untuk melindungi segenap bangsa Indonesia, dan (2) untuk memajukan kesejahteraan umum berdasarkan Pancasila. Hal itu berarti ada dua tujuan nasional, yaitu "perlindungan masyarakat"

(social defence) dan "kesejahteraan masyarakat" (social welfare) yang menunjukkan adanya asas keseimbangan dalam tujuan pembangunan nasional. ${ }^{19}$

Pembaharuan hukum pidana menuntut adanya penelitian dan pemikiran terhadap masalah sentral yang sangat fundamental dan sangat strategis.

19 Barda Nawawi Arief, 2009, Tujuan dan Pedoman Pemidanaan, Badan Penerbit Universitas Diponegoro, Semarang, Hlm. 43
Termasuk dalam masalah kebijakan dalam menetapkan sanksi pidana, kebijakan menetapkan pidana dalam perundang-undangan. Kebijakan legislatif merupakan tahap yang paling strategis dilihat dari keseluruhan proses kebijakan, untuk mengoperasionalkan hukum pidana. Pada tahap inilah dirumuskan garis-garis kebijakan sistem pidana dan pemidanaan, yang sekaligus merupakan landasan legalitas bagi tahap-tahap berikutnya, yaitu tahap penerapan pidana oleh badan pengadilan dan tahap pelaksanaan pidana oleh aparat pelaksana pidana. ${ }^{20}$

Latar belakang dan urgensi diadakannya pembaharuan hukum pidana dapat ditinjau dari aspek sosiopolitik, sosiofilosofis, sosiokultural, atau dari berbagai aspek kebijakan (khususnya kebijakan sosial, kebijakan kriminal, dan kebijakan penegakan hukum). Dengan demikian, pembaharuan hukum pidana pada hakikatnya mengandung makna, suatu upaya untuk melakukan reorientasi dan reformasi hukum pidana yang sesuai dengan nilai-nilai sentral sosiopolitik, sosiofilosofis, dan sosiokultural masyarakat Indonesia yang melandasi kebijakan sosial, kebijakan kriminal, dan kebijakan penegakan hukum di Indonesia. $^{21}$ Singkatnya pembaharuan hukum pidana setidaknya harus menggunakan dua pendekatan, yaitu pendekatan kebijakan (policy-oriented

\footnotetext{
20 Syaiful Bakhri, 2009, Perkembangan Stelsel Pidana Indonesia, Total Media, Yogyakarta, Hlm. 87

${ }^{21}$ Barda Nawawi Arief, Op.Cit., Hlm. 29.
} 
approach) dan pendekatan nilai (valueoriented approach). ${ }^{22}$

Tujuan Pemidanaan (The Aim of Punishment). Tujuan pemidanaan bertolak dari pemikiran bahwa sistem hukum pidana merupakan satu kesatuan sistem yang bertujuan ("purposive system"atau "teleological system") dan pidana hanya merupakan alat/sarana untuk mencapai tujuan, maka didalam konsep KUHP baru merumuskan tujuan pemidanaan yang bertolak pada keseimbangan dua sasaran pokok, yaitu "perlindungan masyarakat" (general prevention) dan "perlindungan/pembinaan individu" (special prevention). ${ }^{23}$

Perkembangan dari pendekatan yang berorientasi terhadap kebijakan ialah lamban datangnya, hal ini dikarenakan bila kita kembali ke awal pembahasan, kebijakan ini dilakukan oleh DPR yang pada dasarnya harus melewati proses legislasi, dan proses legislatif belum siap

22 Pendekatan yang dilakukan terhadap pembaharuan hukum pidana ini dilakukan berdasarkan urgensi diadakannya pembaharuan hukum pidana. Singkatnya pendekatan kebijakan terdiri dari; a. Kebijakan sosial yang bertujuan sebagai penyelesaian masalah-masalah sosial, dan dalam rangka mensejahterakan masyarakat; b. Kebijakan kriminal yang berarti melakukan perlindangan masyarakat (social defence) (khususnya sebagai upaya penanggulangan kejahatan); c. Kebijakan penegakan hukum dalam rangka mengefektifkan penegakan hukum. Serta dalam hal pendekatan nilai pada dasarnya merupakan pembaharuan hukum pidana terhadap muatan normatif dan substansif. Lihat Barda Nawawi Arief, Ibid. Hlm. 29-30.

${ }^{23}$ http://www.legalitas.org/database/artikel/lai n/pokok-

pokok\%20pikiran\%20penyusunan\%20kuhp.pdf , pokok-pokok pikiran penyusunan rancangan undang-undang tentang kitab undang-undang hukum pidana, dakses pada 20 Juli 2017, jam 12.00 . untuk pendekatan yang demikian. Serta masalah yang lain ialah proses kriminalisasi ini yang berlangsung terus menerus tanpa diadakannya suatu evaluasi mengenai pengaruhnya terhadap keseluruhan sistem. Hal ini mengakibatkan timbulnya: a. krisis kelebihan kriminalsiasi; dan b. krisis kelampuan batas dari hukum pidana. ${ }^{24}$

Kebijakan yang ditempuh oleh bangsa Indonesia dalam melaksanakan pembaruan hukum pidana, melalui dua jalur, yaitu:

1. Pembuatan Konsep Rancangan Kitab Undang-Undang Hukum Pidana Nasional, yang maksudnya untuk menggantikan KUHP yang berlaku sekarang.

2. Pembaruan perundang-undangan pidana yang maksudnya mengubah, menambah, dan melengkapi KUHP yang berlaku sekarang.

Masalah utama dalam kebijakan kriminal ialah kriminalisasi, yakni proses diikatnya suatu perbuatan yang sebelumnya tidak diancam dengan sanksi pidana, menjadi perbuatan yang diancam dengan sanksi pidana. Kriminalisasi ini diakhiri dengan diundangkannya suatu perbuatan tersebut.

Jika tujuan pemidanaan bertolak dari keseimbangan dua sasaran pokok, maka syarat pemidanaan menurut didalam konsep KUHP baru juga bertolak dari keseimbangan mono-dualistik antara

${ }^{24}$ Lihat M. Cherif Bassiouni sebagaimana dikutip dalam Barda Nawawi Arie, Hlm. 33-34. 
kepentingan masyarakat dan kepentingan individu. Oleh karena itu, syarat pemidanaan didasarkan pada dua pilar atau asas yang sangat fundamental, yaitu "asas legalitas" (yang merupakan asas kemasyaraktan) dan "asas kesalahan atau culpabilitas" ${ }^{25}$ (yang merupakan asas kemanusiaan atau individual). Bertolak dari ide perlindungan masyarakat, maka didalam konsep KUHP baru tetap mempertahankan jenis-jenis pidana berat, yaitu pidana mati (capital punishment) dan penjara seumur hidup (life sentence).

Namun dalam kebijakan formulasinya juga mempertimbangkan perlindungan/kepentingan individu (ide "individualisasi pidana"), yaitu dengan diadakannya ketentuan mengenai:

a. Penundaan pelaksanaan pidana mati atau pidana mati bersyarat (conditional capital punishment);

b. Dapat diubahnya pidana penjara seumur hidup menjadi penjara 15 tahun apabila terpidana telah menjalani pidana minimal 10 tahun dengan berkelakuan baik, sehingga dimungkinkan terpidana mendapatkan "pelepasan bersyarat" ("conditional release/ parole").

Sedangkan mengenai Pedoman atau Aturan Pemidanaan (Sentencing Guidelines) Masalah keseimbangan antara kepastian atau kekakuan dengan

${ }^{25}$ Andi Hamzah, 1986, Sistem Pidana dan Pemidanaan di Indonesia: dari rettribusi ke reformasi, Pradnya Paramita, Jakarta, Hlm. 45 kelenturan (elastisitas-fleksibilitas) ${ }^{26}$ juga diimplementasikan dalam "pedoman dan aturan pemidanaan", antara lain sebagai berikut:

a) Walaupun sanksi pidana dirumuskan secara tunggal (bersifat imperatif/kaku), namun hakim dapat memilih alternatif pidana lainnya yang tidak tercantum dalam perumusan delik atau mengenakan pidana secara kumulatif dengan pidana lain;

b) Walaupun sanksi pidana dirumuskan secara alternatif, namun hakim dapat menjatuhkan sanksi pidana secara kumulatif;

c) Walaupun sudah ada putusan pemidanaan yang berkekuatan tetap, masih dimungkinkan adanya modifikasi/perubahan/penyesuaia/p eninjauan kembali (asas "modification of sanction"; asas "the alteration/annulment/ revocation of sanction") terhadap putusan tersebut berdasarkan:

a. Adanya perubahan UndangUndang atau perubahan "legislative policy";

b. Adanya perubahan/perbaikan/ perkembangan pada diri terpidana.

d) Walaupun pada prinsipnya konsep RUU KUHP bertolak dari ide keseimbangan, namun dalam hal ada perbenturan antara kepastian hukum dan keadilan, konsep

26 Saleh, K. Wantjik, 1981, Pelengkap KUHP: Perubahan KUH Pidana dan UU Pidana sampai dengan Akhir, Ghalia Indonesia, Jakarta, Hlm. 19 
memberikan pedoman agar "dalam mempertimbangkan hukum yang akan diterapkan, hakim sejauh mungkin mengutamakan keadilan di atas kepastian hukum". 27

Dalam berbagai bentuk tindak pidana (baik WvS maupun konsep baru KUHP) juga diatur tentang adanya "pelaku", "yang menyuruh melakukan", dan "turut serta melakukan" tindak pidana. Logika pertanggungjawaban struktural merupakan kaitan yang boleh jadi menginspirasi atau lalai baik terhadap pengawasan maupun tanggung jawab sehingga terjadinya tindak pidana. Artinya bahwa jelas dalam tindak pidana dan pertanggungjawaban pidana dapat melibatkan pihak lain selain pelaku secara individual. Pertanggungjawaban pidana dalam hal ini tidak bisa dilihat hanya dalam pelaksanaan tindak pidana, tetapi juga memperhatikan hubungan-hubungan psikologis dan historis pelaku tindak pidana, yang tetap harus dalam bingkai rasionalitas. Barda Nawawi mengistilahkan sebagai kebijakan integral dalam penanggulangan kejahatan untuk menyebut pentingnya sistem pemidanaan struktural, yang mengandung arti pula kebijakan integral dalam sistem pemidanaan.

Jadi jenis-jenis pidana yang terdapat didalam Pasal 60 konsep Rancangan KUHP baru adalah sebagai berikut:

clipping.unila.ac.id/2009/07/14/pemidanaanhttp://estruktural-dan-kuhp-baru/ Dakses Pada 09 Juni 2017, jam 12.00. $\underline{\text { Pidana Pokok }}$

a) Pidana Penjara

b) Pidana tutupan

c) Pidana pengawasan

d) Pidana denda, dan

e) Pidana kerja sosial

Sedangkan didalam Pasal 61 Konsep KUHP baru diatur tentang pidana mati, yang dirumuskan sebagai pidana yang bersifat khusus dan selalu diancamkan secara alternative.

\section{$\underline{\text { Pidana Tambahan }}$}

Sedangkan pidana tambahan diatur di dalam Pasal 62 konsep KUHP baru yang menentukan bahwa pidana tambahan terdiri dari:

a) Pencabutan hak tertentu

b) Perampasan barang tertentu dan atau tagihan

c) Pengumuman putusan hakim

d) Pembayaran ganti kerugian

e) Pemenuhan kewajiban hukum adat

Disamping jenis-jenis sanksi pidana yang disebut diatas, konsep KUHP baru juga merencanakan jenis sanksi khusus untuk anak. Jenis sanksi khusus anak ini juga terdiri dari pidana pokok dan pidana tambahan.

Didalam Pasal 109 (1) Konsep KUHP baru ditegaskan, Pidana pokok bagi anak terdiri atas:

a. Pidana Nominal:

1. Pidana Peringatan; atau

2. Pidana teguran keras.

b. Pidana dengan syarat;

1. Pidana pembinaan di luar lembaga; 
2. Pidana kerja social; atau

3. Pidana pengawasan.

c. Pidana denda; atau

d. Pidana pembatasan kebebasab;

1. Pidana pembinaan didalam lembaga;

2. Pidana penjara; atau

3. Pidana tutupan.

Semantara itu didalam Pasal 109 ayat (2) Kosep KUHP baru dirumuskan jenisjenis pidana tambahan bagi anak, yang terdiri atas:

a. Perampasan barang-barang tertentu dan atau tagihan;

b. Pembayaran ganti kerugian; atau

c. Pemenuhan kewajiban adat.

Dari sana dapat kita lihat bahwa anak tidak dikenakan sanksi pidana mati dan pidana penjara seumur hidup. Salah satu dari hal yang baru dalam konsep KUHP baru ini iyalah jenis pemidanaan yang sangat baru di indonesia yaitu pidana kerja sosial disamping masih adalagi konsep baru mengenai pidana denda di dalam pembaharuan hukum pidana ini. Hukum pidana Indonesia yang saat ini berlaku belum mengatur tentang jenis pidana kerja sosial, tetapi masih dirancang dalam Buku I RUU KUHP Tahun 2005. Sosialisaisi rencana pemberlakuan pidana jenis baru ini perlu dilakukan agar memperoleh dukungan dari masyarakat. Ini didasarkan pada pendapat Shelley (1991:5), bahwa:

"Public knowledge of criminal sanctions is not a minor matter, Legislatures often attempt to control crime through general deterrence, meaning that they increase or alter the penalty for an offense in order to deter persons who might commit the offense. But changes in criminal sanctions can scarcely have a deterrent effect if the public is unaware of them. Hence, publicizing a new sanction can be as critical as enacting it".

Secara kronologis, pidana kerja sosial merupakan jenis sanksi pidana generasi ke empat yang muncul karena adanya anggapan bahwa pidana denda (sebagai pidana genarasi ke tiga) kurang efektif jika diterapkan secara luas di masyarakat (Hamzah, 1993:18-21). Pengertian pidana kerja sosial tidak dijelaskan dalam Pasal 83 RUU KUHP. Penulis berpendapat, pengertian pidana kerja sosial adalah jenis pidana berupa pelaksanaan pekerjaan tertentu oleh terpidana di masyarakat tanpa mendapatkan upah, berdasarkan persyaratan yang diatur oleh peraturan perundang-undangan dan Putusan Pengadilan. Dalam konteks ini, putusan pengadilan tersebut dianggap sebagai perintah (orders) terhadap terpidana, yaitu tentang jangka waktu pelaksanaan pidana dan tempat pelaksaaan pidana.

Persyaratan-persyaratan pidana kerja sosial diuraikan dalam Pasal 83 RUU KUHP dan peraturan perundangundangan lainnya. Pidana kerja sosial tersebut dapat digunakan sebagai alternatif pengganti penjatuhan pidana jangka pendek. Uraian ini didasarkan pada ketentuan RUU KUHP Pasal 83 dan penjelasannya, bahwa pidana kerja sosial dapat diterapkan sebagai altertnatif pidana penjara jangka pendek dan denda yang ringan. Secara eksplisit, dalam Buku II RUU KUHP tidak ada 
satu pun tindak pidana yang diancam dengan pidana kerja sosial. Karena itu, ancaman pidana tersebut bersifat alternatif, yaitu jika hakim menganggap bahwa terdakwa layak dijatuhi pidana kerja sosial. Salah satu pertimbangan yang harus diperhatikan dalam penjatuhan pidana kerja sosial adalah harus ada persetujuan terdakwa sesuai dengan ketentuan dalam Forced Labour Convention (Geneva Convention 1930), ehe Convention for the Protection of Human Rights and Fundamental Freedom (Treaty of Rorne 1950), the Abolition of Forced Labour Convention (the Geneva Convention. 1957) dan the International Covenant on Civil and Political Rights (the New York Convention, 1966). ${ }^{28}$

Pidana kerja sosial ini tidak dibayar karena sifatnya sebagai pidana (work as a penalty), oleh karena itu pealaksanaan pidana ini tidak boleh mengandung halhal yang bersifat komersial. ${ }^{29}$ Riwayat sosial terdakwa diperlukan untuk menilai latar belakang terdakwa serta kesiapan yang bersangkutan baik secara fisik maupun mental dalam menjalani pidana kerja sosial. Pelaksanaan pidana kerja sosial dapat dilakukan di rumah sakit, rumah panti asuhan, Panti Lanjut Usia (Lansia), sekolah, atau lembaga sosial lainnya, dengan sebanyak

$28 \quad$ http://syariah.uinsuka.ac.id/file_ilmiah/Pembaharuan\%20Hukum\% 20Pidana.pdf, Pembaharuan hukum pidana Indonesia, Diakses tanggal 12 Juli 2017, jam $15.00 \mathrm{WIb}$.

29 Sudarto, 1986, Pembaharuan Hukum Pidana di Indonesia, salah satu makalah dalam Simposium Pembaharuan Hukum Pidana Nasional, Bina Cipta, Jakarta, Hlm. 7 mungkin disesuaikan dengan profesi terpidana.

Pidana Kerja Sosial dapat dijatuhkan jika musyawarah majelis hakim yang memeriksa suatu perkara memutuskan bahwa terdakwa akan dijatuhi pidana penjara yang lamanya tidak lebih dari 6 (enam) bulan atau pidana denda tidak lebih dari denda Kategori I. Hal ini didasarkan pada ketentuan Pasal 86 ayat (1) dan (2) RUU KUHP. Selain itu, dalam penjatuhan pidana kerja sosial, hakim wajib dipertimbangkan hal-hal berikut: pengakuan terdakwa terhadap tindak pidana yang dilakukan; usia layak kerja dari terdakwa berdasarkan peraturan perundang-undangan yang berlaku; persetujuan terdakwa terhadap kerja sosial, yaitu sesudah dijelaskan mengenai tujuan dan segala hal yang berhubungan dengan pidana kerja sosial; riwayat sosial terdakwa; perlindungan keselamatan kerja terdakwa; keyakinan agama dan politik terdakwa; dan kemampuan terdakwa membayar denda.

Selanjutnya, berdasarkan ketentuan Pasal 86 ayat (3), (4), (5), (6), dan (7) RUU KUHP, diatur bahwa pelaksanaan pidana kerja sosial tidak boleh dikomersialkan. Kemudian, pidana kerja sosial dilaksanakan paling singkat 7 (tujuh) jam dan paling lama: (a) Dua ratus empat puluh jam bagi terdakwa yang telah berusia 18 (delapan belas) tahun ke atas; dan (b) Seratus dua puluh jam bagi terdakwa yang berusia di bawah 18 (delapan belas) tahun. Pelaksanaan pidana kerja sosial dapat 
Failin: Sistem Pidana dan Pemidanaan di dalam Pembaharuan Hukum Pidana Indonesia

diangsur dalam waktu paling lama 12 (dua belas) bulan dengan memperhatikan kegiatan terpidana dalam menjalankan mata pencahariannya dan/atau kegiatan lain yang bermafaat. Jika terpidana tidak memenuhi seluruh atau sebagian kewajiban menjalankan pidana kerja sosial tanpa alasan yang sah, maka terpidana diperintahkan: mengulangi seluruh atau sebagian pidana kerja sosial tersebut; menjalani seluruh atau sebagian pidana penjara yang diganti dengan pidana kerja sosial tersebut; atau membayar seluruh atau sebagian pidana denda yang diganti dengan pidana kerja sosial atau menjalani pidana penjara sebagai pengganti denda yang tidak dibayar.

Oleh karena itu konsep KUHP baru yang idenya adalah keseimbangan, maka upaya untuk mencapai tujuan yang lain yakni keadilan dan kemanfaatan juga akan diakomodasi, yang salah satunya sebenarnya bisa dalam bentuk pengaturan pemidanaan struktural. Apalagi bila mengingat salah satu ide dasar sistem pemidanaan dalam konsep KUHP baru adalah ide mendahulukan keadilan dari kepastian hukum.

\section{SIMPULAN DAN SARAN}

Pembaruan hukum pidana dalam rangka penyempurnaan sistem pemidanaan masih terus dilakukan. Dari sekian banyak hal yang akan diperbarui, satu hal penting dalam sistem pemidanaan yang juga krusial disediakan dalam pembaruan hukum pidana Indonesia adalah sistem pemidanaan struktural.
Tujuan Pemidanaan (The Aim of Punishment). Tujuan pemidanaan bertolak dari pemikiran bahwa sistem hukum pidana merupakan satu kesatuan sistem yang bertujuan ("purposive system"atau "teleological system") dan pidana hanya merupakan alat/sarana untuk mencapai tujuan, maka didalam konsep KUHP baru merumuskan tujuan pemidanaan yang bertolak pada keseimbangan dua sasaran pokok, yaitu "perlindungan masyarakat" (general prevention) dan "perlindungan/pembinaan individu" (special prevention).

Hukum pidana dapat dipahami sebagai bahagian dari keseluruhan hukum yang berlaku di suatu negara, yang mengadakan dasar-dasar atau aturanaluran untuk menentukan perbuatanperbuatan mana yang tidak boleh (dilarang) dilakukan yang disertai dengan ancaman atau sanksi berupa pidana tertentu bagi barangsiapa yang melanggar larangan tersebut.

Maka melalui tulisan ini penulis menyarankan agar pembaharuan hukum pidana di indonesia dapat terlaksana maka selayaknyalah pemerintah mendesak agar segera di sahkannya menjadi sebuah patokan hukum pidana indonesia yang masih memakai warisan belanda. konsep KUHP baru sebagai salah satu konsep pembaharuan hukum pidana di indonesia, adalah sebuah konsep yang di rancang dengan berbagai hukum, baik itu hukum islam dan hukum adat yang di masukkan kedalamnya sebagai suatu rancangan yang hendaknya sesuai dengan masyarakat indonesia. 


\section{UCAPAN TERIMAKASIH}

Puji dan Syukur penulis ucapkan ke hadirat Allah SWT yang telah memberikan Rahmat dan Karunia-Nya, sehingga akhirnya penulis dapat menyelesaikan penulisan karya ilmiah ini yang berjudul: "TINJAUAN SISTEM PIDANA DAN PEMIDANAAN DI DALAM PEMBAHARUAN HUKUM PIDANA INDONESIA"

Penulis menyadari bahwa tanpa bantuan dan dorongan dari berbagai pihak tidak mungkin karya ilmiah ini dapat diselesaikan. Oleh karena itu pada kesempatan ini dengan segala kerendahan hati, penulis ingin mengucapkan terimakasih dan penghargaan yang sebesar-besarnya kepada:

1. Bapak Dr. Eviandi Ibrahim S.H., M.Hum selaku Ketua Sekolah Tinggi Ilmu Hukum Putri Maharaja Payakumbuh

2. Seluruh rekan-rekan Dosen Sekolah Tinggi Ilmu Hukum Putri Maharaja yang tidak dapat penulis sebutkan satu-persatu.

\section{DAFTAR PUSTAKA}

Andi Hamzah, Sistem Pidana dan Pemidanaan di Indonesia: dari rettribusi ke reformasi, Jakarta: Pradnya Paramita, 1986,

Barda Nawawi Arief, Bunga Rampai Kebijakan Hukum Pidana, Bandung: Citra aditia Bakti, 1996,
—, Beberapa Aspek Kebijakan Penegakan dan Pengembangan Hukum Pidana, Bandung: Citra Aditya Bakti, 1998.

Badan Pembinaan Hukum Nasional Departemen Kehakiman, Kitab
Undang undang Hukum Pidana, Jakarta: Pustaka Sinar Harapan, 1988.

Darji Darmodiharjo \& Shidarta, PokokPokok Filsafat Hukukum, Apa dan Bagaimana Filsafat Hukum Indonesia, P.T. Gramedia Pustaka Utama, Jakarta, 1995

Departemen Hukum dan Perundangundangan, Rancangan Undangundang Republik Indonesia Nomor ... Tahun ... tentang Kitab Undang-undang Hukum Pidana, Jakarta, 1999-2000.

Ekaputra, Mohammad dan Abul Khair, Sistem Pidana Di Dalam KUHP Dan Pengaturannya menurut Konsep KUHP Baru, USU Press, Medan, 2010

Jinmmy Asshidigie, Agenda Pembangunan Hukum Nasional Di Abad Glohalisasi, Jakarta: Sinar Grafika, 2000

L.J. van Apeldoorn, pengantar Ilmu hukum, Jakarta: P.T. Pradnya Paramita, 2000

Putusan Mahkamah agung Republik Indonesia tanggal 11 Maret 1970 Nomor 59K/Kr/1973.

Roeslan Saleh, Stesel Pidana Indonesia, Jakarta: Bina Aksara, 1987

Moelyatno, Kitab Undang-undang Hukum Pidana, tt: tp, 1978.

Muladi, Pidana dan Pemidanaan dalam Muladi Dan Barda Nawawi Arief, Teori-teori dan kebijakan pidana, Bandung: Alumni

Saleh, K. Wantjik, Pelengkap KUHP: Perubahan KUH Pidana dan UU Pidana sampai dengan Akhir, Jakarta: Ghalia Indonesia, 1981.

Sudarto, Pembaharuan Hukum Pidana di Indonesia, salah satu makalah dalam 
Failin: Sistem Pidana dan Pemidanaan di dalam Pembaharuan Hukum Pidana Indonesia

Soetiksno, Filsafat Hukum Bagian I, PT. Pradnya Paramita, Jakarta, 2008

Simposium Pembaharuan Hukum Pidana Nasional, Jakarta: Bina Cipta, 1986.

Syaiful Bakhri, Perkembangan Stelsel Pidana Indonesia, (Yogyakarta: Total Media, 2009).

Wirjono Prodjodikoro, Asas-Asas Hukum Pidana di Indonesia, PT. Refika Aditama, Bandung, 2008

\section{INTERNET}

http://syariah.uinsuka.ac.id/file_ilmiah/Pembaharua
n\%20Hukum\%20Pidana.pdf, Pembaharuan hukum pidana Indonesia, Diakses tanggal 20 juli 2017, jam 10.00 WIB

http://repository.usu.ac.id/bitstream/handl e/123456789/21543/Chapter\%20II .pdf;jsessionid=E49E02C84094B1 CD73517FFA85AB3C93? sequenc $\underline{\mathrm{e}=3}$, diakses pada hari jumat, tanggal 18 Agustus 2017, pada jam 12.00 WIB

http://e-

clipping.unila.ac.id/2009/07/14/pe midanaan-struktural-dan-kuhpbaru/ Dakses Pada 09 Juni 2017, $\begin{array}{lll}\text { jam } & 12.00 \quad \text { WIB. }\end{array}$ 